\title{
EXPRESSION OF THE HISTORY OF THE PEOPLES OF CENTRAL ASIA IN PHOTOS
}

\author{
Jakhongir Gopurjonovich Inoyatov
}

Doctoral student (PhD), Chirchik State Pedagogical Institute

\section{ABSTRACT}

In this article, the author aims to shed light on the evolution of scientific approaches in this field by studying the history of world photography. As well as the art of photography of the peoples of Central Asia and its importance in modern photography today. The main point of the article is to provide a comprehensive coverage of the formation of modern technologies by analyzing the scientific research in history through an in-depth study of the history of photography.

KEYWORDS: - Evolution, scientific approaches, world photography, Central Asia, modern photography, evolution of scientific approaches, scientific research, modern technologies.

\section{INTRODUCTION}

Shortly after the invention of the camera, its "miracle" became an important source in the study of Central Asian history. The photograph was first taken in this area in the mid-19th century by P.P. Used by an expedition led by Semenov. Many important and interesting historical information about the history of Central Asia can be found in the photos in the Turkestan album. The Turkestan album was compiled by order of the Governor-General of Turkestan and published in 1874 by AdjutantGeneral K.P. von Kaufmann, and contains a very large collection of photographs.

"Turkistan album" is an album of photos and color pictures. Prepared by the ethnographer, orientalist A.L.Kun (1840-88) on the instructions of the Governor-General of Turkestan KP Kaufman in 1871-72. The "Album of Turkestan" consists of 447 pages, 1262 photos and paintings. The book was divided into sections on handicrafts, archeology and history. Crafts of the mid-19th century in the "Turkistan Album"; types of economy, customs and rituals, anthropological types of Uzbeks, urban and rural life, landscapes of cities and valleys. The aim of most of the images is to portray the local people as savage and backward. "Turkistan album" is made in 7 copies. One copy is kept in the department of rare books of the National Library of Uzbekistan. ${ }^{1}$.

\section{Methods}

The Turkestan album was the result of many years of work under the guidance of A.L. Kun, a Central Asian researcher. It features paintings of mountains, glaciers, and architectural monuments of major cities in the region. They include an ethnographic section that introduces locals to occupations, types of portraits, and

\section{CURRENT RESEARCH JOURNAL OF HISTORY \\ ISSN - 2767-472X}


CURRENT RESEARCH JOURNAL OF HISTORY 2(5): 66-70, May 2021

DOI: https://doi.org/10.37547/history-crjh-02-05-16

ISSN 2767-472X

(C)2021 Master Journals

Crossref doi 81 Google

Accepted 25 $5^{\text {th }}$ May, 2021 \& Published 31th May, 2021

genre scenes. $^{2}$

The Turkestan album was the result of many years of work under the guidance of A.L. Kun, a Central Asian researcher. It features paintings of mountains, glaciers, and architectural monuments of major cities in the region. They include an ethnographic section that introduces locals to occupations, types of portraits, and genre scenes. $^{3}$

It is no coincidence that today this glacier is called Barshchevsky.

The first color photographs of Central Asia, ie Turkestan, were first taken by Russian photographer Sergei Prokudin-Gorsky (18631944).

Sergei Prokudin also took color photos of the famous Amir Alimkhan. He came to Turkestan in 1906-1907 and visited Samarkand, Bukhara, Tashkent and dozens of other towns and villages.

Sergei Prokudin-Gorsky takes hundreds of photos about the landscapes of Turkestan, the life of its people. He wanted to create a photogallery panorama to show how vast the territories and colorful nations the empire of Emperor Nicholas II was.

In 1918, during the turbulent years of the revolution, Sergei Prokudin-Gorsky emigrated to France. His descendants will move to the United States. Unique photographs of our country, our homeland and our people are now housed in the Library of Congress.

Leon (Lev) Semyonovich Barshchevsky was born in 1849 in Warsaw to a family of gentlemen. An

\footnotetext{
2 Туркестанский альбом. 1871-1872. В 4-х частях. По распоряжению Туркестанского Генерал-Губернатора К. П. Фон Кауфмана І-го. Точное воспроизведение издания: Спб. 1873 г. 16 c.

3 Липский В.И. Горная Бухара: Результаты трехлетних путешествий в Среднюю Азию в 1896, 1897 и 1899 годах. 4.1-3. СПб., 19021905. -4.1. - 318 е.; 4.2. - С.319-541.; Ч.3. - С.542-735.
}

early orphan, the boy was raised by his older sister. Like many middle-class people, Leon chose the military profession, and in 1866, after graduating from the military gymnasium in Kiev, he entered the military school of Constantine. After graduation, Barshchevsky entered the infantry school in Odessa. When asked about the "Polish uprising" in history class, he defended the rebels, for which he was removed from the student list and transferred to the Kherson regional regiment with the title of hunker. There, Leon actively began to study language and crafts, and took photography lessons from watercolor artist and photographer Nikolai Osipov. After the annexation of Turkestan to Russia in 1876, Barshchevsky applied to move to Turkestan, one of the conditions for obtaining the highest military ranks in the Russian Empire. Leon Barshchevsky was sent to Central Asia in 1889.

Leon Barshchevsky, a Polish traveler who tried to study the history of Central Asia in depth, traveled long distances throughout Central Asia, and VI Lipsky, who came to Central Asia in 1898 to study the Pamir glaciers, also made important photographs on the history of the region. This expedition of scientists was able to take many photographs of historical significance throughout Central Asia. For example, photographs taken on the glacier on the southern slope of the Gissar ridge are of great importance in the study of Central Asian history. These are the first photographs taken in Central Asia.

The whole Central Asian period of his life was connected with Samarkand and Penjikent, and in 1896 he graduated from the Turkestan service with the rank of lieutenant colonel. Leon Barshchevsky studied the life and customs of the local people in the Zarafshan valley and photographed their lives. His photographs are a unique document of the history of that period and Central Asia. Through the organization of scientific expeditions, Barshchevsky traveled along the rivers Zarafshan, Fandarya, 
CURRENT RESEARCH JOURNAL OF HISTORY 2(5): 66-70, May 2021

DOI: https://doi.org/10.37547/history-crjh-02-05-16

ISSN 2767-472X

(C)2021 Master Journals

\section{Crossref dof 80 Google}

Accepted 25 $5^{\text {th }}$ May, 2021 \& Published 31 ${ }^{\text {th }}$ May, 2021

Iskanderdarya and Yagnob, through which he went to the Gissar ridge and the Emirate of Bukhara. $^{4}$

Methodological research: We know from history that the life, culture, nature, climate, way of life and traditions of the peoples of Central Asia are expressed through unique photographs, as well as the plight of the people of this country during the former empire. In 1905, on behalf of Emperor Nicholas II, Prokudin-Gorsky embarked on his first creative tour of Russia, during which time he created about 400 photographs of the Caucasus, Crimea and Lesser Russia. His photographs were very popular at the time. Because he does not use black-and-white photographs, but color photographs during his travels. Prokudin-Gorsky achieves such creative success through the method of stacking negatives on top of each other. This innovative approach makes the Russian tourist one of the pioneers of color photography.

In May 1908 his second voyage began. The photographer travels to the North Caucasus - but from time to time he returns to Moscow and St. Petersburg to cover the life of the Romanov family through photographs. In the same year, Prokudin-Gorky created several colorful portraits of Leo Tolstoy in Yasnaya Polyana. This is the author's first and only color photo.

Prokudin solemnly photographed a photograph of Bukhara's Amir Alimkhan (1880-1944) shortly after he came to power in 1911. This digital color image is stored in the Printing and Photography Division of the Library of Congress, LC-DIG-ppmsc-03959 (5) ${ }^{5}$.

As the ruler of the autonomous city-state in Muslim Central Asia, he ruled the internal affairs of the Emirate as an absolute monarch from the

\footnotetext{
${ }^{4}$ Императорский фарфоровый завод 1744-1904. СПб., издание управления Императорскими заводами, 1906.. 460 с.

${ }_{5}^{5}$ https://www.loc.gov/exhibits/empire/ethnic-ru.html
}

middle of the 19th century, despite the fact that Bukhara was a vassal state of the Russian Empire. After the establishment of Soviet power in Bukhara in 1920, the emir fled to Afghanistan. Perhaps his most famous photograph taken in Central Asia is a portrait of Muhammad Alimkhan, the last emir of Bukhara, who appears to have been photographed during the filming of this historic drama. Like Prokudin-Gorsky, the emir fled the Bolsheviks and left his country. Both died in 1944, a photographer in Paris and an emir in Kabul.

\section{Results}

From 1905 to 1915, the photographer made several expeditions to Central Asia in the Russian Empire. At that time it included Osh, Samarkand, Tashkent, Kokand, Andijan and other large cities and regions. All surviving photographs of Prokudin are kept in the Library of Congress. The photographer's collection also includes photographs taken in dozens of cities in the former Russian Empire. For example, he works on a color photo of a silk and cotton seller in Samarkand. This photo depicts a page of the Qur'an sitting on a multi-layered fabric and hanging from the ceiling in a unique style. Prokudin also photographed a melon seller and the Syrdarya Bridge in the Fergana Valley. He photographed a caravan of camels carrying food through the steppes of Central Asia, as well as the Soviet-era cities of Yangier and Gulistan.

Many peoples of Central Asia, such as the Kyrgyz, Kazakhs, and Uzbeks, led nomadic lifestyles in the steppes, valleys, and deserts, and moved from place to place as the seasons changed as food, water, and shelter opportunities changed. This photo, taken by Prokudin, shows a young family dressed in colorful traditional costumes moving across the steppe in modern-day 
CURRENT RESEARCH JOURNAL OF HISTORY 2(5): 66-70, May 2021

DOI: https://doi.org/10.37547/history-crjh-02-05-16

ISSN 2767-472X

(C)2021 Master Journals

\section{Crossref dof 80 Google}

Accepted 25th May, 2021 \& Published 31 th May, 2021

Uzbekistan and Kazakhstan. This digital color image is stored in the Printing and Photography Division of the Library of Congress, LC-DIGppmsc-03979 (6) .

Samarkand, the ancient commercial, intellectual, and spiritual center of the Silk Road from Europe to China, was inhabited by Tajiks, Persians, Uzbeks, Arabs, Jews, and Russians. Another photo taken by Prokudin shows a group of traditionally dressed Jewish boys studying with their teacher. This digital color image is stored in the Printing and Photography Division of the Library of Congress, LC-DIG-ppmsc-04442 (7).

Prokudin-Gorsky's portrait of an Uzbek woman also features a traditional Uzbek woman's dress, jewelry, and hairstyle on a carpet at the entrance to the house, or a mobile tent used by Central Asian nomadic peoples to build houses. After the conquest of Turkestan in the mid-19th century, the Russian government put severe pressure on the nomadic peoples, encouraging them to adopt a sedentary lifestyle and live permanently in villages and cities.

\section{Conclusion}

In late 1906, during Sergei Prokudin-Gorsky's first trip to Central Asia, he accompanied the expedition of the Russian Geographical Society to observe a solar eclipse in the Tien Shan Mountains on January 1, 1907, 111 years ago. Because the day was cloudy for astronomy, the photographer took the opportunity to photograph nearby Samarkand, its architecture and its people. As a professional chemist, Prokudin-Gorky developed one of the first methods of color reproduction by combining three glass white and black negative plates shot through different color filters: red, green, and blue. In some paintings, the colors are surprisingly realistic.

So Prokudin-Gorsky's exotic "others" photos are still popular today. For example, we see the skill of taking pictures of men wearing turbans selling fresh bread on the street or near a mosque. It is also worth noting that the photos of women in very long-sleeved coats were made in a unique photo style, so as not to freeze their hands. He also described the details of the monumental ancient architecture in a unique style. Today, these buildings are recognized as the most important Islamic architectural structures in the world. The Prokudin-Gorsky archives are housed in the Library of Congress in Washington, D.C., and many of the photographs taken by the photographer and his notebooks are also available online. There are many more Central Asian paintings by Prokudin-Gorsky. That is why we consider it important for the younger generation to get acquainted with the works of such photographers in order to give them a good idea of their ancestors.

\section{REFERENCES}

1. https://lcsr.hse.ru/news/44341947.html

2. Туркестанский альбом. 1871-1872. В 4x частях. По распоряжению Туркестанского Генерал-Губернатора К. П. Фон Кауфмана І-го. Точное воспроизведение издания: Спб. 1873 г. $16 \mathrm{c}$.

3. Липский В.И. Горная Бухара: Результаты трехлетних путешествий в Среднюю Азию в 1896, 1897 и 1899 годах. 4.1-3. СПб., 19021905. -4.1. - 318 е.; 4.2. - С.319-541.; Ч.3. - C.542-735.

4. Императорский фарфоровый завод 1744-1904. СПб., издание управления Императорскими заводами, 1906.. 460 c.

5. https://www.loc.gov/exhibits/empire/et 
CURRENT RESEARCH JOURNAL OF HISTORY 2(5): 66-70, May 2021

DOI: https://doi.org/10.37547/history-crjh-02-05-16

ISSN 2767-472X

(C)2021 Master Journals

Crossref dof 81 Google

Accepted 25 $5^{\text {th }}$ May, 2021 \& Published 31th May, 2021

hnic-ru.html

6. https://www.loc.gov/exhibits/empire/et

hnic-ru.html

7. https://www.loc.gov/exhibits/empire/et hnic-ru.html

8. Rasuljanovna, I. N., \& Rakhmonqulovich, K. N. (2020). Trade Relations Between Ancient Bacteria And China On The II-I BC. The American Journal of Social Science and Education Innovations, 2(07), 47-51. 